\title{
Ethical Issues in School Educational Management
}

\author{
BIBHUTI NARAYAN BISWAL*
}

Principal, Sri Sathya Sai Vidyaniketan,Ganeshvad Sisodra, N.H No. 8, Navsari396463, Gujarat, India

*Email: bibhuti.nb@gmail.com

Received: January 25, 2016| Revised: January 27, 2016| Accepted: February 25, 2016

Published online: March 07, 2016

The Author(s) 2016. This article is published with open access at www.chitkara.edu.in/publications

\begin{abstract}
Education in general has always been seen as a vehicle of social transformation and socio-politico-cultural-economic dynamics. Powerful, knowledge society of India need good quality education in $21^{\text {st }}$ century. It has been said politics without principles, business without morality, education without character are equally dangerous for our country. Today the whole world is passing through corporate chaos such as Satyam Infotech, 2G spectrum allocation scam, Vyapam scam, Coal-gate and institutional conundrum such as suicide of students, sexual harassment of teachers and students, exploitation of employees etc are to name a few. It is often reported that a few unprincipled people are always behind such scams and incidents. It is in this context ethical issues in school educational management has been conceived so as to give respite to present debacles. According to [8] ethics in teaching of higher education cover: content and pedagogical competency, fair assessment, respect to stakeholders, professional conduct, student development, reasonable pay, perks and leaves, avoidance of dual relationships, counselling to students and parents and involvement in community development. The paper highlights the urgency of ethical practices in school education and offers pragmatic solutions such as : Emphasis on vision \& mission of school, do's and don't do's for educational managers, use of affirmative language, ethical documentation \& dissemination. Institution of IQAC \& ethics committee in school, enforcing POCSO act 2012, following "W-A-T-C-H" Model, Ethical performance appraisal / promotion and reward and conflicts management etc. By managing man ethically (method) money, materials', machines and market can be conquered with the help of quality education.
\end{abstract}

Keywords: Affirmative language, IQAC \& ethics committee, conflicts management
Issues and Ideas in Education Vol- 4, No- 1 March 2016 pp. 29-36 
Indian education is at a historic cross road today owing to its unprecedented expansion, less control over quality, changing learning landscape of learners, intrusion of a breed of non performing teachers, ICT revolution, government policy without financial accountability, mushrooming of private players with dubious intentions of social service \& nation building etc. School education is considered as the bedrock of higher education. It is believed that the school's success is directly proportional to the effective management of people to work harmoniously together with an orientation towards the vision or mission of the school. Such management includes participation in decision-making, forming into effective teams with sustained motivation and developing a congenial atmosphere in the school.

The major function of school is learner development; enhancement of social access to higher education; nation building through extension programmes for community development; advancement of research. It is the change agent to reach a large body of youngsters in the age group of 6-18years in the country who are to be shaped in their most impressionable age to develop sensitivity to quality in intellectual attainment; to assume roles as responsible citizens and leaders to determine the destiny of the country; and to acquire a cultural identity and values which bridge tradition and modernity. Good schools pays equal emphasis to curricular aspects, teaching - learning and evaluation, research and extension, infrastructure and learning resources, student support and progression, organisation and management, healthy practices, value fostering practices etc. According to [9] it is argued that principles of care and compassion and principles of justice are compatible with each other and can be integrated in organizations in such a way that both will supplement each other. Hence organisations with strong root in value practices \& healthy practices sustains all challenges during their growth \& developmental stages like a tree that withstands severe blow of cyclone due to its deep rooted strength. Therefore ethical practices in school not only gives necessary impetus for its strong image in society but also ensures its sustainability.

\section{COMMISSIONS/ COMMITTEES ON ETHICAL PRACTICES IN SCHOOLS}

The Mudaliar commission on secondary education felt that the supreme end of the educative process should be training of character and personality of student in such a way that they will be able to realize their full potential and contribute to the well being of the community. We need to inculcate the qualities of discipline, tolerance, patriotism, cooperation, world citizenship and morality in our children. It must be the responsibility of each and every teacher 
to provide the education of character through every single aspect of school programme. The Sri Prakasa Committee on religious and moral instructions also emphasized that the teaching of moral and spiritual values in educational institutions was desirable and the inculcation of good manners, social service and true patriotism should be continuously stressed and true patriotism should be continuously stressed at all stages. The Kothari education commission opined that our education system should emphasize on the development of fundamental social, moral and spiritual values. Education used to be an important tool for inculcation and cultivation of values, morals, and attitudes for character building of the individual. Investment in education reaffirmed that human beings were positive assets and precious national resource that need to be nurtured and developed.

\section{RATIONALE OF ETHICS IN SCHOOL EDUCATION}

Ethics is defined as the practical sciences of morality of human conduct. In other words it is concerned with the norms of human behaviour. Ethics in school encompasses the domain of behaviour that is exhibited by schools to distinguish between right and wrong. Our schools must define their work ethics for the realization of objectives of education. [2] Education is for life and not merely for living. It is not mere accumulation of information but values in action. This attitudinal orientation and value inputs would go a long way in creating future managers with openness to new idea, readiness to learn from others. Our schools must ponder over the lofty ideals of practicing ethics in its day to day affairs which is depicted in fig. 1.

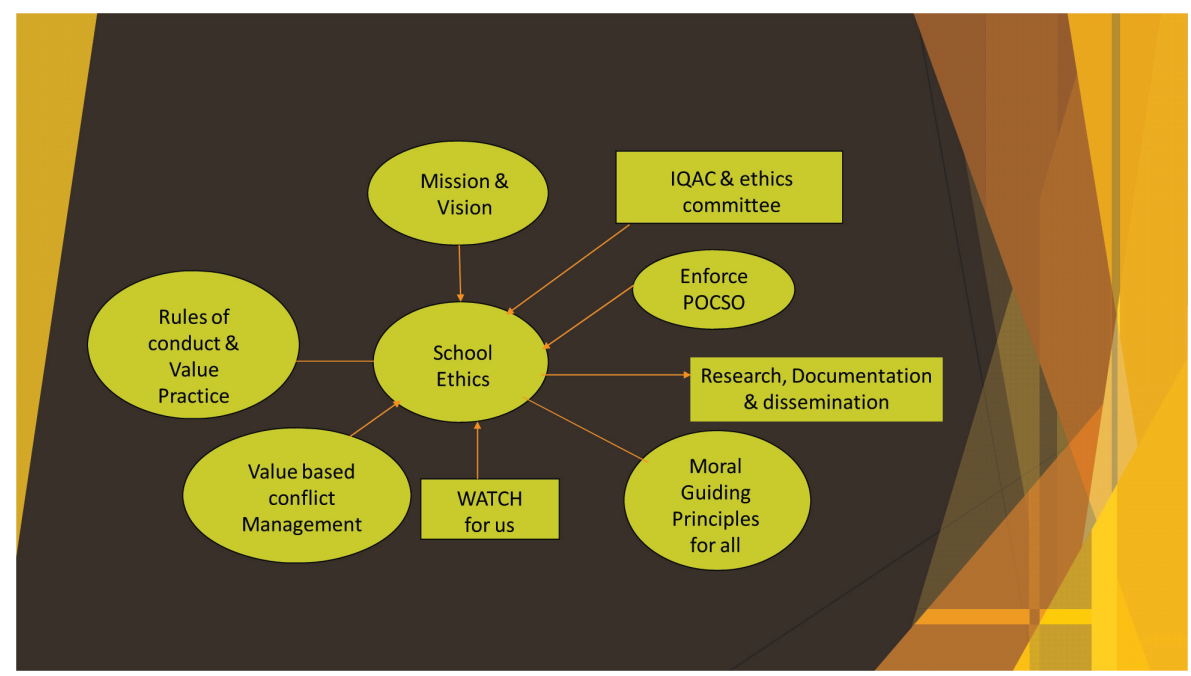

Figure 1 : School Ethics (Pictorial Imagination).
Ethical Issues in

School Educational

Management 
A goal with embedded value is like a dream with deadline.Ethics education has been a neglected area of education management in our country though it was an integral part of social discourse for a long time.

\section{ETHICAL ISSUES IN SCHOOL}

Schools are seen today suspiciously by parents, teachers, educators, administrators, union members \& business persons, people inside and outside the school walls. Also schools face severe value crisis which has direct bearing on quality of the schooling as well as quality of outputs. Several unethical practices that mars the purpose of schools are : contract employment strategy, drill \& Practice approach in school academic affair management, deliberate crocodile cry towards realization of educational objectives, use of one size fits for all formula in learning process, no action for minimum level of learning, low rate of employee's retention, no policy for teacher appointment, promotion and retention, no heed to learning of individual child, raising eyebrows to special govt. policies like RTE and RTI act etc are to name a few. Hence it is very much essential that institutions of learning should be designed and run as learning organizations by practicing ethics in all walk of schooling.

\section{HOW TO MANAGE ETHICS IN SCHOOL}

We are what we repeatedly do, excellence then is not an act but a habit. Here a pertinent question arises whether we have to prepare ethical ground or practical ground in our educational affairs? Certainly answer lies in between two maxims. According to [7] "......Education can and must bring fine synthesis between change oriented technologies and country's continuity of cultural traditions. This can be considered as ethical values of education, but this will usher a way to quality education. Also schools can be made sustainably vital and creative not by fiat and command or by regulations or forced rankings, but by adopting learning orientations i.e. [6] involving everyone in the system in expressing their aspirations, building their awareness and developing their capabilities together. Here are some of the time tested pathways of ethical approach to educational management problems.

\section{a) Emphasis on Vision \& Mission of school}

True Education not for a mere living, but for a fuller and meaningful life. So every school should have mission statement, value framework and clearly stated vision. The mission and vision of school should be shared with parents, Teachers, Students sufficiently, efficiently and consistently from time to time. 


\section{b) Do's for educational managers}

Work for the people in the organization, use bottom up approach in management, actively address the pressing need of education, encourage inclusiveness in classroom, respect RTE \& RTI, strive to reach all learners by discouraging one size fits for all formula in learning process, adore no child left behind policy, ensure minimum level of learning, high rate of employee retention, follow ethical process in teacher appointment, promotion and retention.

\section{c) Use of affirmative language}

School is a beautiful sanctuary and fortress for student upbringing and they should be treated fairly without any discriminations. It is the bounden duty of school to preserve the self esteem of each leaner irrespective of their talent, abilities. Therefore school should create a culture of appreciating learners in several ways. Such as :use of reinforcing terms like differently abled in place of disable, handicapped children in place of children with special needs etc. We must learn to love each child as they are and count our blessings each day in various ways. Let us not forget that manner of living is more important than standard of living. [3] If a child lives with criticism, he learns to condemn. If a child lives with praise he learns to appreciate. If a child lives with hostility he learns to fight. If a child lives with tolerance he learns to be patient. If a child lives with encouragement, he learns confidence. If a child lives with security he learns to have faith. If a child lives with acceptance and friendship, he learns to find love in the world.

\section{d) Documentation / dissemination}

The underlying rationale for raising school documentation is that continuous improvement is more likely to occur if it is effectively reported and analysed with the explicit agreement of the vision of the school. A slight deviation in reporting or raising false document or distorted report may augur irreparable loss to the school in long run. Thus fair report, authentic documentation can act as a catalyst in branding schools image.

\section{e) Institution of IQAC \& ethics committee in school}

Quality is the buzz word of $21^{\text {st }}$ century. It is impossible to imagine anything like any product or services without having any quality. Same is the case for schools. One of the major objectives of all the schools to become successful is to improve the quality of teaching-learning, managing relationship internally as with external agencies which needs continuous internal supervision. To meet such need Internal Quality Assessment Cell is a must for all schools which can work independently, transparently and fairly manner.
Ethical Issues in

School Educational

Management 
Biswal, B. N.

Looking at present context of various categories of harassments and exploitations such as sexual abuse, child abuse, harassment at work place, it is essentials for school management to constitute committees like ethics committee, Committee for prevention of harassment of women, Protection of rights committee etc.

\section{f) Protection of Children from Sexual Offence (POCSO) Act 2012}

All children have an equal right to access education in an environment that is safe, protective and conducive to the overall development. The challenges of gender inequality, eve teasing and sexual abuse in school environment call for increased awareness and creating synergy among parents, teachers and schools. CBSE has taken initiative of (POCSO) Act in 2012 for creating awareness about sexual exploitation among the school children. All schools need to support it for its strict implementation in real sense so as to ensure rights of every children to have access to education.

\section{g) FOLLOWING “W-A-T-C-H” Model}

Practice Panchakshari Mantra "WATCH" i.e W: - watch your words, A: - watch your actions, $T$ : - watch your thought, $C$ : - watch your character, $H$ : - watch your heart / habit. By doing so we can bring harmony in the system, synergy among stake holders for the collaboration in making school successful. [4] Its possible to do what you love- if not in your job, at least leisure time. Work is love make it visible.

\section{h) Performance Appraisal / Promotion and Reward}

Active involvement of the different stakeholders in the internal management of the schools is increasingly viewed as an effective means of promoting and improving school. In this context it is imperative to keep records of involvement of all stake holders (mainly teachers) for their working periods for which higher authority needs to make entries. Some time it has been noticed that stranded relationship comes in to the performance appraisal process \& making entry in service books which act as a counterproductive one in schools's growth and development. So such activities must be discouraged in schools for its smooth functioning.

\section{i) Conflicts Management}

In the organizational environment, awareness of each employee's nature is critical to success, at least those who are in key performance and decision- 
making positions. [5] When such employees are self-aware, workplace conflict can be minimized and can become productive to the organization. But when these employees are not aware of their nature these conflicts can become destructive for the individual as well as for the organization. [1] Conflicts are the part and parcel of any school management process. It should be viewed as a natural and expected part of working in teams and as a learning opportunity rather than as a personal threat or attack. There are two types of conflict affective conflict and cognitive conflict. Affective conflict is personal anger or resentment usually directed at individuals rather than ideas, whereas cognitive conflict is a difference of opinion on an issue or an idea. If it is viewed in those positive terms it can be understood and managed. Successful management of conflict is about turning affective conflict into cognitive conflict; that is moving the focus off the person and on to the issue. Further cognitive conflict over issues is a desirable aspect of teamwork because it opens spaces for divergent thinking, creativity and open communication; all of which contribute to greater team effectiveness.

\section{CONCLUSION}

Life is a journey from ' $\boldsymbol{I}$ ' to ' $\boldsymbol{w} \boldsymbol{e}$ '. Therefore by practicing and cultivating good work culture in school will certainly take the institution a long way for which we have to curate and script our growth story now by incorporating ethical practices and adhering to the supreme principle of Truth, righteousness, love and non violence in our thought-words and actions. Institution comes and goes but that institution sustains which adheres to high moral practices. Great purpose- great minds can create great institutions and we must follow our hearts while managing our institutions.

\section{REFERENCES}

[1] Amason et al, 1995 as cited by Mitchell, C. \& Sackney. L. (2000). Profound improvement: Building capacity for a learning community. Lisse: Swets and Zeitlinger.

[2] Bhaskar, R.K.,(2009) Man management, Sri Sathya Sai Student\& Staff welfare society, Prashanthinilayam (A.P).

[3] Chona, S.(2015) Learn to accept your child for what he /she is, Progressive Teacher, Vol. 2 No. 05.

[4] Mattews, A (1997) Follow Your Heart, Embassay Books, Mumbai.

[5] Modh, S (2014) Formulating a New Three Energy Framework of Personality for Conflict Analysis and Resolution based on Triguna Concept of Bhagavad Gita, Journal of Human Values, 20(2) 153-165.

http://dx.doi.org/10.1177/0971685814539415
Ethical Issues in

School Educational

Management 
Biswal, B. N. [6] Senge, P (2012) Schools that Learn, Crown Business, New York.

[7] Singh, R.K (2015) Postulating a coruscating kaleidoscope of Ersatz affairs: Higher Education in India, University News, Vol. 53, No. 43.

[8] Suar, D.(2014) Ethics in Teaching, Journal of Human Values, 20(2) 117-127. http://dx.doi.org/10.1177/0971685814539408

[9] Zia, S,A.; Kitchlew, N.; Shahzad, K (2014) Integrating Principles of Care, Compassion and Justice in Organizations: Exploring Dynamic Nature of Organizational Justice, Journal of Human Values, 20(2) 167-181.

http://dx.doi.org/10.1177/0971685814539411 